\title{
РОБОТА 3 ІНОЗЕМНИМИ СТУДЕНТАМИ: ОСНОВНІ ТРУДНОЩІ ТА ШЛЯХИ ЇХ ПОДОЛАННЯ
}

\author{
С. В. Чугін
}

Запорізький держсавний медичний університет

\section{WORK WITH FOREIGN STUDENTS: THE MAIN DIFFICULTIES AND POSSIBLE WAYS OF THEIR SOLVING}

\author{
S. V. Chugin
}

\author{
Zaporizhzhia State Medical University
}

\begin{abstract}
У статті розглянуті основні труднощі в процесі адаптації та навчання іноземних студентів у медичному університеті, проаналізовано можливі шляхи їх вирішення.

The article discusses the main difficulties in the process of adaptation and education of foreign students at medical university, and possible ways of their solving was analyzed in the article.
\end{abstract}

Вступ. Інтеграція сучасної української системи вищої медичної освіти в європейську ставить нові завдання та умови розвитку експорту освітніх послуг. Це прямо пов' язано з підвищенням конкурентоспроможності медичних вишів на міжнародному ринку освіти. Крім цього, навчання іноземних студентів $\epsilon$ певним показником статусу навчального закладу. На сьогодні в Україні значно збільшилася кількість вищих навчальних закладів, що приймають на навчання іноземних громадян $[1,2]$. У зв'язку з цим стає актуальним вивчення проблем адаптації іноземних студентів до освітнього процесу у медичному виші. Водночас не менш важлива позиція і діяльність самого вищого навчального закладу щодо створення адекватних умов навчання та побуту, що сприяють ефективному процесу адаптації до академічного та соціального середовища та успішності іноземних студентів. При цьому особливе місце відводиться новому соціокультурному середовищу, значним психологічним, емоційним і фізичним навантаженням, інтенсивності процесу навчання, професійній спрямованості навчання, значній навчальній зайнятості студентів, координації навчання між навчальними дисциплінами [2]. Адаптація іноземних громадян до нових соціокультурних умов при вступі до вищого навчального закладу є основоположним чинником, що визначає в більшості випадків ефективність освітнього процесу в цілому. Тому проблема адаптації іноземних студентів до умов навчання в медичному вузі

(C) С. В. Чугін стає значущою і вимагає педагогічного наукового вирішення. Тому мета статті полягає в розкритті основних труднощів і шляхів їх подолання при роботі з іноземними студентами.

Основна частина. Структура i зміст навчання в Запорізькому державному медичному університеті орієнтовані на майбутню спеціальність / напрям підготовки, а виховний процес - на особистісний ріст іноземних студентів. Разом з тим, ми виявили ряд труднощів, з якими стикаються іноземні студенти, особливо в перший рік навчання, в ході соціокомунікативної адаптації, а саме: психофізіологічні, пов'язані з перебудовою особистості, “входженням” у нове студентське наукове середовище, психоемоційним напруженням, зміною клімату тощо; навчально-пізнавальні труднощі, пов'язані, в першу чергу, з недостатньою мовною підготовкою, подоланням відмінностей у системах національної освіти; адаптацією до нових вимог і системи контролю знань; організацією навчального процесу, який повинен будуватися на принципах саморозвитку особистості, "вирощування" знань, “прищеплення” навичок самостійної роботи; соціокультурні труднощі, пов'язані з освоєнням нового соціального і культурного простору вишу; подоланням мовного бар'єра у вирішенні комунікативних проблем з адміністрацією факультету, викладачами та співробітниками вишу, так і в процесі міжособистісного спілкування всередині міжнаціональної малої навчальної групи, навчального потоку, на побутовому рівні $[3,4]$. 
Аналіз літературних джерел і власний досвід роботи в ЗДМУ дозволяють виділити кілька шляхів вирішення даної проблеми подолання адаптаційного баp'єра іноземними студентами: перегляд та оновлення основних цілей і завдань, змісту освіти, виховання з позиції необхідності переходу іноземного студента в нове для нього суспільне середовище; переважання особистісно-орієнтованої моделі навчання, в центрі якої стоять інтереси, потреби, можливості особистості іноземного студента як суб'єкта освітнього процесу, їх спільна діяльність, що базується на позитивній взаємодії; формування умов для подолання “дидактичного бар'єра" вищої освіти, різних національних освітніх систем (включення у навчальний план спеціальних дисциплін; англомовне викладання у виші; забезпеченість відповідною науковою та навчально-методичною літературою; спеціальна підготовка викладачів; російськомовна підготовка іноземних студентів на підготовчому факультеті та ін.); інтеграція різноманітних засобів трансляції морального досвіду в умовах підготовки активної, заповзятливої, компетентної, а відповідно, конкурентоспроможної особистості, націленої на самоосвітню діяльність $[3,4]$. Крім того, формування процесу адаптації іноземних студентів до навчання в ЗДМУ може бути успішним за тієї умови, якщо організація освітнього процесу здійснюється на основі взаємодії дисциплін медичного та гуманітарного циклів; інтеграції різних видів діяльності; застосування сучасних педагогічних навчальних технологій, що відповідають завданням професійної підготовки іноземних студентів, а також взаємодії учасників освітнього процесу.

Основним підрозділом ЗДМУ, діяльність якого пов'язана з роботою з іноземними студентами, є деканат міжнародного факультету. 3 метою подолання адаптаційного бар'єра в процесі навчання деканат виконує не тільки координацію навчального процесу, але й аналіз, моніторинг, розробку заходів по безперервному поліпшенню основних компонентів навчального та позанавчального процесів.

Практично всі іноземні студенти-медики проходять етап довузівської підготовки на підготовчому відділенні. Подоланню адаптаційного бар'єра на початковому етапі вивчення загальнотеоретичних дисциплін в російсько- та англомовної аудиторії має сприяти поступове впровадження у навчальний процес особистісно-орієнтованих технологій навчання і контролю знань, які в даний час використовуються в медичному виші.

Однією з актуальних проблем, що стояли перед колективами кафедр ЗДМУ, був пошук сучасних методик навчання і контролю знань студентів із різним рівнем базової підготовки, представників різних етносів і культур. Реалізація завдань впровадження інноваційних форм освітньої діяльності в конкурентному середовищі вимагає від викладачів кафедр в контакті 3 керівництвом факультету великих зусиль. Зокрема, у зв'язку зі складністю засвоєння студентами навчального матеріалу та медичної термінології останнім часом інноваційна діяльність співробітників кафедр спрямована на створення мультимедійних лекцій-презентацій, впровадження активних форм i методів навчання на практичних заняттях, організації самостійної роботи студентів (СРС) і тестового контролю знань з урахуванням психолого-педагогічних аспектів при впровадженні інформаційних технологій. Наприклад, презентація дає викладачеві можливість самостійно скомпонувати навчальний матеріал 3 конкретної теми дисципліни, а отже, створити умови для максимального засвоєння навчального матеріалу. Крім того, використання мультимедіа дозволяс активізувати і когнітивні процеси, від яких значно залежать i якість навчання, i виконання програмного навчального матеріалу, наголошуючи на його опорні елементи й концентруючи увагу студентів [4].

Хотілося б відзначити, що на першому курсі медичного факультету іноземні студенти мають різний базовий рівень загальноосвітньої та мовної підготовки, різний ступінь засвоєння російської та латинської мов та анатомічної термінології. За обмежений термін студенту доводиться засвоїти величезну кількість відомостей, позначень, цифрових характеристик. При цьому студент не завжди встигає встановити смисловий зв'язок між даними, що підлягають запам'ятовуванню. Все це вимагає від викладача будь-якої фундаментальної дисципліни, зокрема анатомії людини, постійно вдосконалювати методику викладання, пов'язану з демонстрацією та контролем засвоєного студентами матеріалу, правильно і раціонально керувати роботою студентів. У цьому плані важливим $€$ розвиток зв'язків з викладачами підготовчого факультету, кафедрами гуманітарного спрямування та міжнародним деканатом [5].

Майстерність викладача здатна підвищити ефективність і процесу навчання, і процесу виховання. Основна роль при цьому належить позааудиторній роботі, яка $€$ ефективним засобом розвитку гармонійної і грамотної особистості іноземного студента, хоча формально в навчальний процес і не входить. Позааудиторна робота включає широкий спектр заходів, спрямованих на ознайомлення і прийняття студентами соціально-правових норм країни, пристосування 
до нових кліматичних умов, адаптацію до української освітньої системи; знайомство з правилами поведінки в громадських місцях; попередження негативних явищ соціального характеру; ознайомлення з культурою і традиціями України. При цьому ії форми можуть бути різними, наприклад, проведення різноманітних тематичних екскурсій, відвідування кінотеатрів і театрів, вечори, присвячені національним святам і традиціям, бесіди та диспути, творчі та поетичні конкурси, олімпіади та багато іншого $[3,5]$.

\section{Списоклітератури}

1. Иванова М. А. Психологические аспекты адаптации иностранных студентов к высшей школе / М. А. Иванова. С Пб. : Нестор, 2002. - С. 81.

2. Портрет образовательного мигранта. Основные аспекты академической, языковой и социокультурной адаптации : колл. монография / науч. ред. Е. Ю. Кошелева. - Томск : РАУШ МБХ, 2011.-204 c.

3. Мишина Н. В. Вопросы психолого-педагогической адаптации иностранных студентов к учебному процессу на клинической кафедре / Н. В. Мишина, С. И. Ильченко, Т. В. Ярошевская // Достижения и перспективы внедрения кредитно-модульной системы организации учебного про-
Висновок. Таким чином, структура та зміст навчання в ЗДМУ спрямовує свою діяльність не лише на подолання адаптаційного бар'єра, але й на формування цілісної особистості іноземного студента, здатної усвідомлено отримувати знання, сприймати їх нерідною мовою, переробляти, зберігати, примножувати і реалізовувати в соціальній практиці, у всіх системах життєдіяльності, перш за все, у навчальній діяльності у медичному виші.

цесса в высших медицинских учебных заведениях Украины (Тернополь, 15-16 мая 2014 г.) : в 2 ч. - Тернополь : ТГМУ,2014. - Ч. 2.

4. Моднов С. И. Проблемы адаптации иностранных студентов, обучающихся в техническом университете / С. И. Моднов, Л. В. Ухова // Ярославский педагогический вестник. -2013. - Т. I, № 2.-С. 111-116.

5. Адаптация первокурсников: проблемы и тенденции / Л. Н. Боронина, Ю. Р. Вишневский, Я. В. Дидковская [и др.] // Университетское управление: практика и анализ. 2001. -№4 (19). - С. 178. 